250 working days in the year, the total annual saving to be gained by the switch would be $£ 20$ million.

\section{Safety in High Blocks}

A PRELIMINARy report on the collapse of a 23 storey block of flats in East London last week confirms the opinion that the accident was caused by an explosion and not by any structural defect. The public inquiry into the collapse which will be held shortly will be headed by Mr Hugh Griffiths, recorder of Cambridge, and with him there will be a civil engineer and a fuel engineer. In the meantime, research in Britain into the safety of tall blocks seems to be non-existent. The Building Research Station, the only establishment in the country working entirely on building research, is not saying whether any research has been done there on the safety of tall blocks, in case the inquiry might be affected, but the Directorate of Research and Information (DRI) of the Ministry of Public Building and Works which has now undertaken a review of research in the construction industry, believes that no specific inquiries of the safety of tall buildings have been carried out.

Industrialized building methods for tall blocks have been in use for many years now, but the lack of any research into safety indicates that the dangers of such buildings have not been enough to warrant a research programme. If research is recommended by the public inquiry, this would come into the field of the DRI, which at present spends about $£ 130,000$ a year on building research. Established in 1962, the DRI is part of the Directorate General of Research and Development of the Ministry of Public Building and Works, with responsibility inside the ministry for policy on construction research and information. It also provides a background for the inquiries of the Construction Research Advisory Council under Sir Michael Cary, which was set up in November 1967 by the minister to advise on the best use of the national effort in building research. In the research field, as well as making a review of existing research and pointing out areas which would benefit from investigation, the DRI sponsors research in universities to the

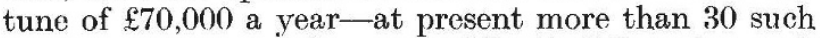
projects have been financed. The Building Research Station is now run through the DRI and of the $£ 60,000$ a year it spends, a quarter goes to universities for sponsored projects.

Information and industrial liaison are two important aspects of the DRI's work. As well as producing reports and advisory leaflets, the information group is hoping this year to begin publication of a quarterly journal on research and development in the construc. tion industry - no mean task, it seems, because it will have to be printed by the often slow-moving Stationery Office. Industrial liaison groups are dealing with building maintenance and computer applications. In the maintenance field the group is investigating such questions as the quantity and quality of maintenance work and the length of time the designers and constructors are responsible for a building -in Britain this is often only six months, while in France the period is more like ten years. The section dealing with applications of computers is to establish a construction industry computer centre which will be particularly useful for the smaller firms.

\section{Parliament in Britain}

$$
\text { by our Parliamentary Correspondent }
$$

\section{Nuclear Power}

There were a number of questions about the bid the UK Atomic Energy Authority has made to build a nuclear power station for Imatran Voima, of Finland. Mr Edmund Dell, for the Board of Trade, said that the Government was doing all within its power to support the AEA tender. The EFIA convention required that the award of the contract be made on commercial grounds, he added. Mr Wedgwood Benn, the Minister of Technology, said that the AEA and himself were completely convinced that the Steam Generating Heavy Water Reactor on offer in Finland was technically and commercially competitive with the other tenders. (Oral and written answers. May 15.)

\section{Grain Beetle}

WAS the Minister of Agriculture aware, Mr Kitson asked, that the saw-toothed grain beetle was not in this country 5 years ago, but that it was here now" What was he going to do about it? Mr John Mackie, for the minister, said that he had been accused of a number of things, but this was a new one. He did agree that the beetle was a pest, but said that its eradication was commercially impractical. Advice could be given for fumigation and the like, he suggested. (Oral answer, May 15.)

\section{Nuclear Fall-out}

Mr Nerl Marten asked the Prime Minister what would happen in the event of nuclear fall-out spreading as a result of a civil nuclear disaster. The Prime Minister replied that such an occurrence was highly improbable, but the related departments "would have a role to play in inter-rclated contingency plans". Mr Marten wanted to know what would happen when civil defence was disbanded next year. Mr Wilson suggested that the skill of the AEA could be provided in the event of such a disaster. (Oral answer, May I4.)

\section{Organ Transplants}

Mr Kenneth Robinson, the Minister of Health, refused to name the members of the Conference on Organ Transplantation. Nor would he list their qualifications, invite Members of Parliament to join the conference. publish a report of their deliberations, list the times, dates and places of the meetings, or say what arrangements he had made for the submission of written evidence to the conference. All he would do was to say that the conference would have a second meeting next month. (Written answer, May 14.)

\section{Rabies}

Mr John Mackie, for the Minister of Agriculture, said that the last case of the death of a dog from rabies in Britain was in 1949. A leopard cub had dicd in November 1965. Sir Richard Glyn, who asked for the figures, said that only three or four animals had developed rabies in quarantine in Britain in the past 20 years. and the great majority of animals coming into Britain capable of carrying rabies had not passed through quarantine. Mr Mackie said that the disease was a terrible one if it got into humans, and that no precautions could be too great. Dr John Dunwoody said that Britain was almost unique in having had no case of rabies for very many years. This showed the value of the regulations. Mr Mackie agreed. (Oral answer. May 15.) 